\title{
Practitioners' conceptions of ethical practice in social networking in career services
}

\author{
Jaana Kettunen ${ }^{1}$ (D) Julia Panke Makela ${ }^{2}$
}

Received: 30 April 2018 / Accepted: 1 November 2018 / Published online: 9 November 2018

(C) The Author(s) 2018

\begin{abstract}
This article reports on a phenomenographic investigation into practitioners' conceptions of ethical practice in social networking in career services. The results show that ethical practice was conceived as stemming from: (1) an information orientation, (2) a networking orientation, (3) an educational orientation, and (4) a collaborative orientation. Differences appeared along six dimensions including: approach, activities, level of usage, perception, strategy and ethical principles. The findings give us a more profound understanding of critical aspects that may have an important role in relation to further developments and the successful implementation of existing and emerging technologies in the career service sector.
\end{abstract}

Keywords Career services · Ethics · Phenomenography

\section{Résumé}

Les Conceptions de Pratique Éthique de Réseautage Social chez les Praticiens des Services d'Orientation Professionnelle Cet article est une étude phénoménologique des conceptions de pratique éthique de réseautage social chez les praticiens des services d'orientation professionnelle. Les résultats indiquent que la pratique éthique a été conçue comme provenant de : 1) une orientation à l'information, 2) une orientation au réseautage, 3) une orientation à l'éducation, et 4) une orientation à la collaboration. Des différences sont apparues sur six dimensions : l'approche, les activités, le niveau d'utilisation, la perception, la stratégie, et les principes éthiques. Les résultats nous donnent une compréhension plus profonde des aspects critiques qui pourraient jouer un rôle important dans le développement futur et l'implémentation réussie des technologies existantes et émergeantes dans le secteur de l'orientation professionnelle.

\section{Zusammenfassung}

Vorstellungen von Praktikerinnen und Praktikern von ethischer Praxis des sozialen Netzwerkens im Rahmen von Angeboten der Berufs-, Studien- und Laufbahnberatung Dieser Artikel berichtet über eine phänomenographische Unter-

Extended author information available on the last page of the article 
suchung der Vorstellungen von Praktikerinnen und Praktikern von ethischer Praxis des sozialen Netzwerkens im Rahmen von Angeboten der Berufs-, Studien- und Laufbahnberatung. Die Ergebnisse zeigen, dass ethische Praxis als Folge von: (1) einer Informationsorientierung, (2) einer Netzwerkorientierung, (3) einer Bildungsorientierung und (4) einer kollaborativen Orientierung betrachtet wurde. Unterschiede zeigten sich entlang von sechs Dimensionen, darunter: Ansatz, Aktivitäten, Nutzungsgrad, Wahrnehmung, Strategie und ethische Prinzipien. Die Ergebnisse geben uns ein vertieftes Verständnis für kritische Aspekte, die bei Weiterentwicklungen und der erfolgreichen Implementierung bestehender und neuer Technologien im Bereich der Berufs-, Studien- und Laufbahnberatung eine wichtige Rolle spielen können.

\section{Resumen}

Conceptos de práctica ética en las redes sociales de los profesionales de los servicios de orientación Este artículo nos informa sobre una investigación fenomenográfica sobre los conceptos de práctica ética en las redes socials de los profesionales de los servicios de orientación. Los resultados muestran que la práctica ética fue concebida como derivada de: (1) una orientación informativa, (2) una orientación en red, (3) Una orientación educativa, y (4) una orientación colaborativa. Aparecían diferencias a lo largo de seis dimensiones incluyendo: enfoques, actividades, nivel de uso, percepción, estrategia y principios éticos. Los resultados de la investigación nos dan un profundo conocimiento de los aspectos críticos que pueden tener un importante papel para promover desarrollos y aplicaciones que tengan éxito en las tecnologias existents y emergentes en el sector de los servicios de orientación.

\section{Introduction}

A growing number of career practitioners and career centres are reaching out to individuals and community members in new ways by integrating social networking sites such as Facebook and LinkedIn into their professional practices (e.g., Dyson, 2012; NACE, 2013; Osborn and LoFrisco, 2012). Social networking can be used both to deliver and to market career services and is considered an efficient tool for those seeking career assistance, providing convenient access and building community and social support among individuals with similar interests and needs (e.g., Hooley, Hutchinson, \& Watts, 2010; Kettunen, Vuorinen, \& Sampson, 2015b; Van Allen \& Roberts, 2011). Employers are also highly active on social media and social networking platforms as social networking meet a number of needs including vacancy advertising (Jobvite, 2013), attraction and recruitment (Carrillat, D’Astous, \& Morissette Grégoire, 2014) and screening (e.g., Caers \& Castelyns, 2010; Melanthiou, Pavlou, \& Constantinou, 2015). Similarly, job seekers use social media and social networking to search for vacancies, to develop job networks (Niles \& Harris-Bowlsbey, 2013) and to vet potential employers (Jobvite, 2014). As technological advances change how individuals explore and acquire information about education, training and work opportunities, there is a pressing need to align new technologies more closely with career services and 
associated professional practices (e.g., Kettunen, 2017). This changing contexts requires career professionals to think carefully about whether and how to utilise social networking in their practice and support and educate clients, employers and related service providers who have embraced these resources (e.g., Makela, 2015; Sampson \& Makela, 2014).

Social networks are web-based services that allow individuals to construct a public or semi-public profile within a bounded system; to list other users with whom they share a connection; and to view and traverse their own connections and those of others within the system (Boyd \& Ellison, 2007). This relationship and community building emphasis encourages two-way communication, in which people share information about themselves, view information about others, and store information for future reference. Here, we distinguish social networking technologies (SNTs) as a subset of social media. The term 'social media' refers to the wider process through which Web 2.0 technology enables individuals and groups to build a common understanding and shared meaning through content and communities (Ahlqvist, Bäck, Heinonen, \& Halonen, 2010; Kolbitsch \& Maurer, 2006). Web 2.0 technologies can, in turn, be characterised as user-centred, open, participatory, interactive and knowledge sharing (e.g., Kolbitsch \& Mauer, 2006). In other words, social media refers primarily to practices rather that to a particular technologies (Bonderup Dohn, 2009).

A number of studies have examined the ethical issues around to the use of existing and emerging technologies in career practice (e.g., Barak, 2003; Makela, 2015; Malone, 2007; Sampson, 2002; Sampson \& Makela, 2014). Careful consideration has also been given to the skills and competencies that practitioners require in order to use these technologies (e.g., Barnes, La Gro, \& Watts, 2010; Barnes \& Watts, 2009; Bimrose, Barns, \& Attwell, 2010; Cedefop, 2009; Cogoi, 2005; Pyle, 2000, Watts, 2002), and more specifically, social media (Kettunen, 2017; Kettunen, Sampson, \& Vuorinen, 2015a) in a career services context. According to Sampson and Makela (2014), these ethical issues relate to social equity, validity of resources, availability of user support, confidentiality, privacy and boundary crossing. The rapid development of technology also makes it difficult to adhere to ethical guidelines such as using only validated tools and maintaining professional competence with selected resources (Van Allen \& Roberts, 2011). The boundaries between private and professional lives and the relationship between client and a career professional can become blurred, as private details be inadvertently or inappropriately accessible through social networking (e.g., Bateman, Pike, \& Butler, 2010; DiLillo \& Gale, 2011; Osborn, Dikel, \& Sampson, 2011), complicating ethical commitments related to informed consent, privacy, confidentiality, and data security. Additionally, online data are collected and stored on computers that professionals do not control (e.g., Bateman et al., 2010) and can be archived, copied, forwarded of or shared out of context. In many cases, data are not destroyed on a predetermined timeline as professional standards recommend. Concern has also been expressed about digital exclusion of groups who are not connected or engaged in online interactions, and who may therefore miss out on relevant services (e.g., Bimrose, Hughes, \& Barnes, 2011; Hooley et al., 2010, Kettunen \& Sampson, 2018). This sensitivity to digital 
exclusion reflects the more general ethical commitment to fair and equitable treatment for all citizens.

Professional associations have also recently developed ethical guidelines for the use of social networking and social media in career services. For example, in an update to its ethical guidelines, the International Association for Vocational Guidance (IAEVG) states that 'members are responsible for monitoring and maintaining their professional competencies and for ensuring that they are able to provide competent services to diverse clientele effectively using contemporary assessment processes, theories, intervention techniques, and technology and social media resources' (IAEVG, 2017, p. 6). In the United States, the National Career Development Association's recently revised Code of Ethics (NCDA, 2015) included a section on social networking and social media as a resource for career professionals in relation to the ethical implications of integrating social networking technologies into their practice.

As interactive online platforms continue to grow in popularity and influence, there is an onus on career professionals to engage in critical reflection on the ethical issues associated with social networking (Sampson \& Makela, 2014). While many such issues have been identified, practitioners are not always clear about how to deal with them (e.g., Bratt, 2010; Kettunen et al., 2015a, 2015b), and a more nuanced understanding is needed. On that basis, the present study examined career practitioners' conceptions of ethical practice in their use of social networking.

The main aim of this phenomenographic study is to identify and describe the qualitatively different ways in which practitioners understand ethical practice in social networking in career services. There are two key research questions: (1) What are career practitioners' conceptions of ethical practice in social networking in career services? and (2) What are the critical aspects that differentiate qualitatively varying ways of understanding ethical practice in social networking in career services? In describing the variation in conceptions, the ultimate aim is to expand understanding of critical factors for successful implementation and use of existing and emerging technologies in the career service sector.

\section{Methods}

The study adopted a phenomenographic approach (Åkerlind, 2005b; Marton, 1986; Marton \& Booth, 1997; Marton \& Pong, 2005), which focuses on participants' experiences, understandings or conceptions of a particular phenomenon at the collective level (Marton \& Booth, 1997). Phenomenography is grounded on the premise that there is a limited number of ways of experiencing a particular phenomenon, and that these are logically related. Previous phenomenographic studies have examined conceptions of the role of ICT in relation to national guidance policies (Kettunen, Vuorinen, \& Ruusuvirta, 2016), leadership and management in guidance and counselling networks (Nykänen, 2011), and career practitioners' conceptions of social media in professional context (Kettunen, Vuorinen, \& Sampson, 2013). The primary outcome of phenomenographic analysis is a structured set of logically related categories that describe the qualitative variation 
in people's ways of experiencing or understanding the phenomenon in question (Marton, 1986). According to Marton and Booth (1997), such categories of description should meet three criteria of quality each category should describe in a distinct way of conceiving the phenomenon, the logical relationship between categories should be hierarchically represented and the categories describing variation across the sample should be parsimonious and limited in number. The process used to ensure the quality of descriptions is described in the data analysis section.

\section{Study context and participants}

In line with the phenomenographic approach (Åkerlind, Bowden, \& Green, 2005; Marton \& Booth, 1997), a varied sample was deliberately sought in order to maximise the diversity of participants' understandings (Åkerlind, 2005b). Emails inviting practitioners with experience of social networking were sent to all career professionals attending the National Career Development Association (NCDA) global conference. The conference was selected as the primary site because the Association's membership encompasses a wide range of professional settings. Participants were also recruited at general sessions throughout the conference by means of advertisements. Using purposive sampling, participants' experience of social networking guided selection (Patton, 2002) to ensure information-rich cases yielding significant amounts of data of relevance to the study. Previous phenomenographic studies suggest that, once the sample is selected to ensure maximum variation, between 10 and 15 subjects is normally sufficient to capture the variation (Åkerlind, 2008; Trigwell, 2000). The participants were 24 career practitioners ( 22 women and 2 men) with some experience of using social networking in their professional work ( 9 daily, 9 weekly, 1 monthly and 6 less than once a month), as well as in their personal lives. Those who regularly engaged (at least monthly) social networking technologies in their professional work, on average, reported using 2.6 distinct resources (with a range of 1-5 social networking technologies reported). On the whole, social networking technologies most commonly used in professional work included LinkedIn (22 participants), blogs (14), Facebook (12) and Twitter (11). Participants reported frequent use limited to their personal lives most frequently associated with Facebook (7), blogs (2), and Twitter (1). Participants reported infrequent use (no use to less than monthly use) in both their professional work and personal lives regarding Twitter (12), blogs (8), Facebook (5), and LinkedIn (2). These usage patterns demonstrate a variety of approaches to social networking technology. Participants also came from a variety of settings, both urban and rural, including colleges and universities, private practice and business and industry. The distribution of reported age ranges was as follows: four were under 30 years old; eight were aged 30-39 years; six were aged 40-49 years; three were aged 50-59 years, two were aged 60 or older, and one participant did not disclose their age. Data collection formed part of a twoyear project conducted by the NCDA Ethics Committee prior to revising the Technology section of the NCDA Code of Ethics, which was published in 2015. 


\section{Data collection}

Because the primary aim of this study was to investigate a range of understandings of the same phenomenon, focus group interviews were used to gather the data (Bogdan \& Biklen, 2006; Kitzinger \& Barbour, 1999; Krueger, 1997a, 1997b, 1998). This method was considered appropriate as a means of encouraging participants from different contexts to express their thoughts, views and experiences while interacting with each other and because phenomenographic research seeks to capture collective, rather than individual accounts of the diversity of experiences and understandings of the phenomenon. Additionally, there is some evidence that this population is particularly receptive to focus groups (e.g., Kettunen, et al., 2015a, 2015b; Nykänen, 2011).

In total, seven focus groups were conducted, each comprising three to six career practitioners from various contexts. The first of these was a pilot session (prior to the conference), to test the process and to evaluate the questions. As there were only minor changes in the phrasing of questions, the data from the pilot session were included in the study. At the beginning of each 1-h focus group, participants completed a demographic form that included questions about their use of social networking at work and in daily life. The subsequent discussion was divided into two main parts. First, participants were asked to reflect on their perceptions of the use of social networking in practice, focusing on the benefits, drawbacks and potential ethical issues. Participants were then presented with a case scenario involving an ethical dilemma and were asked to work through it by defining ethical issues, identifying ideal resolutions and brainstorming strategies for practice. To identify strategies that would be applicable across practice environments and social networking platforms, each focus group addressed one of four randomly assigned scenarios, all of which had been pilot tested. The issues included professional boundaries, privacy and confidentiality, professional integrity and public trust in career service-related social networking. Interview questions were informal and conversational, allowing participants to elaborate their current understandings and experiences as fully and openly as possible. Neutral follow-up questions were used to encourage participants to elaborate or clarify their responses, as in the following examples 'Could you tell a bit more about that?' 'Could you describe it/explain it a little further?' 'Could you give an example of it?' When asking follow-up questions, the facilitator was careful to avoid leading practitioners' responses. Digital recordings of the focus groups were transcribed verbatim for analysis.

The purpose and value of revisiting the data here is to unpack some deeper insights into career practitioners' conceptions of ethical practice in social networking in career services and to identify critical aspects which may play an important role in further development and successful integration of existing and emerging technologies in this context.

\section{Data analysis}

The phenomenographic analysis of the data (Åkerlind, 2005b; Kettunen \& Tynjälä, 2017; Marton \& Booth, 1997; Marton \& Pong, 2005) was performed in three phases, following the guidelines and examples provided by Åkerlind (2005a, 2005b), 
Bowden (2000a), and Bowden and Green (2005, 2010). The first phase of analysis focused on identifying and describing conceptions of ethical practice in social networking in career services in general terms. To that end, transcripts were considered as a whole and were repeatedly re-read to obtain and identify the underlying foci and intentions expressed in them. Reference to the entire transcript (or to large sections) is intended to improve accuracy of interpretation of participants' responses (Akerlind et al., 2005). To identify key relationships and distinct characteristics, subsequent readings focused on similarities and differences in the meanings expressed. Gradually, by comparing and contrasting identified similarities and differences, draft descriptive categories for collective meaning were developed, defined and named.

The second phase of the analysis sought to delineate the logical relationships among the various categories. Themes that ran through and across the data were identified and used to structure these relationships both within and between the categories (Åkerlind, 2005a). The aim was to distinguish between more and less complex ways of seeing the phenomenon (Åkerlind, 2005a; Marton \& Booth, 1997), to broaden awareness of its different aspects. Throughout this phase, the initial categories of description were further elaborated, fixed and defined according to the characteristic features of each category, with constant reference to the data.

To ensure robust analysis, the data were initially analysed by the first author, and a second opinion was then sought from research colleagues, with whom she met several times. Discussing and revising the categories and their structures in this way served to confirm the valid interpretation of the data. Acting as a critical friend, research colleagues probed the category candidates and their critical aspects and sought justifications from the transcripts for any given formulation. As emphasised by Bowden (2000b), this group process made it less likely that analysis would cease prematurely, and helped to minimise the researcher's individual perspective, ensuring loyalty to the data in formulating the categories of description. Iterative re-reading and re-drafting were repeated until saturation-that is, until re-reading failed to produce any significant changes in the categories of description (Bowden \& Green, 2010). The authors have experience of qualitative research, phenomenography and use of ICT in career services.

The final phase of analysis focused on ensuring that the categories of description fulfilled the quality criteria mentioned earlier, as specified by Marton and Booth (1997): that each category described a distinct way of experiencing the phenomenon; that the logical relationships between categories were hierarchical; and that in describing variation across the sample, the categories were parsimonious and limited in number.

\section{Results}

Analysis of the data revealed four distinct categories of description reflecting career practitioners' conceptions of ethical practice in social networking (Table 1). Ethical practice in social networking was conceived as stemming from: (1) an information orientation, (2) a networking orientation, (3) an educational orientation, and (4) a collaborative orientation. The differences between the categories appeared along 
six dimensions of variation that included: approach to social networking, social networking activities, level of usage, perception, social networking strategy and ethical principles.

Each of the categories in Table 1 is further clarified below in selected excerpts from relevant written responses. It is important to note that this categorization represents collective-rather than individual—conceptions of ethical practice in social networking in career services.

\section{Description of the Categories}

Category 1: Information orientation In the first category, ethical practice in social networking is conceived from an information perspective. The approach to social networking is technology focused, meaning that emphasis is placed on operational understanding of social networking tools and ways of using these for the purpose of accessing and disseminating work related information.

Besides LinkedIn, there's Zuum, and there's all these other ones. But at least be knowledgeable about the most mainstream or the most popular social media. (participant 12, line 2781)

I could just take a peek at what others were talking about and what they're posting...it just calls things to my attention that I'm interested in. (participant 9 , line 871)

It's just a way to get information out to our constituents and to let people know what we're doing and what we're involved in. (participant 15, line 4186)

In this category, practitioners' use of social networking is experimental, with an attempt to explore the phenomenon, its utility and functionality in the context of career services. They perceive the use of social networking technologies for professional purposes as a challenge. The challenges relate to time consumption, choice of tools and resources, and the transparent, open nature of social networking. The primary concern is a perceived lack of professional guidance for developing appropriate practices.

There's so much going on with it; I find that pretty challenging to take time to delve in... (participant 11, line 1611)

I've been grappling with this. I'm a very ethical person and I like to follow rules and I've been kind of looking for guidance. (participant 12, line 1738)

Practitioners also express ethical concerns about the accuracy and validity of information-especially the information they present and share online. They employ private social networking strategies and use social networking in a closed way.

[In terms of posting on social media] one of the things that I think about from the career services side of things in terms of posting on social media is making sure that the information that we're putting out is authoritative or accurate. (participant 1, line 346) 


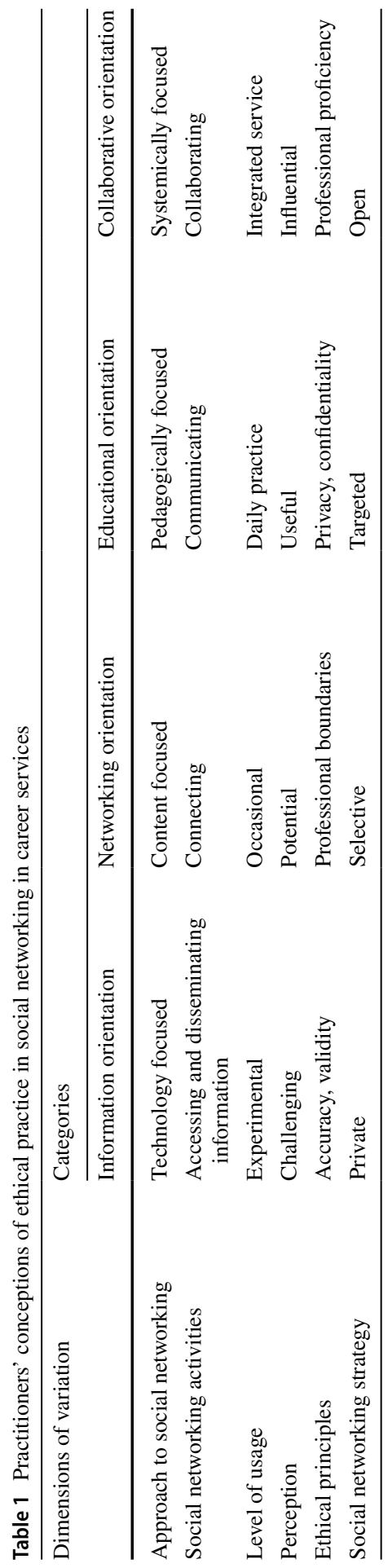


My standard approach is that I don't connect with clients, and I think that that's consistent with our ethical codes. (participant 9, line 960)

Category 2: Networking orientation In the second category, ethical practice in social networking is conceived from a networking perspective. This approach to social networking is content focused, emphasising proficiency in various forms of online content and social networking for building connections as well as accessing and disseminating information.

I think it helps students connect with a much wider variety of people that they otherwise might not be able to connect with. Whether it's alumni, or employers, or whatever else, focusing back on their job search. (participant 3, line 8)

I use LinkedIn as a resource for networking. I mean, using LinkedIn as getting them a way to plug into a community and feel like they can find people that they can make a connection with. (participant 13, line 3254)

I find that it is a lot easier for me to stay connected with my colleagues [in social networks]. (participant 10, line 811)

In this category, practitioners use social networking occasionally, rather than on a regular basis, perceive social networking as having positive potential for professional practice in general. They indicate that social networking sites offer an effective way of sharing and interacting with online content and connecting with a defined group of people. Additionally, practitioners believe that social networking may help to attract people to career services.

I think there's a lot of potential [in using social networking technologies in professional practice]. (participant 11, line 1604)

It is very easy to promote our services and promote our center to a wide audience very cheaply and very quickly. (participant 4 , line 14 )

However, practitioners express ethical concerns about the professional boundaries that might be blurred by social networking. For that reason, they adopt a selective social networking strategy, connecting thoughtfully and using social networking in a semi-open way.

Professional/personal blurred. Recruiting and just networking blurred. I think that our old distinctions are uncomfortably being dissolved. (participant 16, line 4268)

I do connect with students through LinkedIn but many more students request than I actually know. So deciding which ones are appropriate to be a LinkedIn connection and which ones are just a student that happens to be at the University [is difficult]... (participant 5, line 248)

Category 3: Educational orientation In this third category, ethical practice in social networking is conceived as stemming from an educational perspective. Emphasis is placed on multidirectional real-time or near-real-time communication and activities that foster career learning, acquisition of career management skills and 
employability. Practitioners highlight the importance of supporting and educating individuals; one aspect of this is helping clients to make effective use of social networking for career development.

Professionals can $[\ldots]$ have real time conversations via Twitter or Facebook or LinkedIn that are happening exactly at that moment, so there is no delay. (participant 16, line 4190)

I think a big part of the challenge for us, as career services, is that education piece and helping them understand that they're leaving this permanent digital footprint, and that this is branding you in a certain way. How do you take this space and utilize it for its value without allowing it to negatively impact you? (participant 4, line 123)

These practitioners use social networking technologies in their daily practices and perceive social networking as highly useful. They indicate that social networking sites offer an effective way of building and cultivating networks, facilitating conversations and connections and creating access to job opportunities for clients.

I use it every day with my job seekers. (participant 12, line 1731)

I go on Facebook just about every day because I can find different things that I need. (participant 10, line 931)

In this category, practitioners' concerns extend beyond professional boundaries in social networking to privacy and confidentiality issues. Practitioners adopt a targeted social media strategy, connecting for work purposes and using social networking in a semi-open way. They systemically construct a network of those who might be helpful in finding or recommending a job of the kind they want.

I purposely try to connect with people who are HR people. (participant 12, line 2086)

I go for quality over quantity, too. I don't accept every invitation that's sent to me. Not to say I won't accept it from someone I don't know, but there has to be sort of a compelling reason. (participant 12, line 1997)

Category 4: Collaborative orientation In this fourth category, ethical practice in social networking is conceived as stemming from a collaborative perspective, in which practitioners' approach is systemically focused. Emphasis is placed on wellstructured and considered professional goals and on strategies that fit those goals. Attention is also given to ensuring that common guidelines and/or social networking policies are in place.

And now, we need to have more of a strategic direction. (participant 11, line 1616)

I've actually just gone through a strategic process of what will be our unit's online presence.... we'd rather focus in on a couple of things, do them really well, and have that really be the consistent point, and then leave other things for other times. (participant 14, line 3337) 
Having some kind of policy that you can follow. (participant 16, line 4964)

Unlike in previous categories, the emphasis here is on fostering collaborative career exploration with and among community members. Social networking both mediates social interactions with others and facilitates knowledge-sharing practices within and across organizational boundaries.

Being able to share professional experiences whether its employment, volunteering, internships - that sort of thing. (participant 23, line 6577)

Here, social networking is no longer seen as an alternative tool but as a workspace that is in itself an integral part of career services and an effective means of enhancing the direct and indirect influence of career services. By operating as members and facilitators of communities of individuals career practitioners indicate that they can more readily take steps to address and respond to career-related discussions that emerge.

Okay, now, it's [social networking] definitely an integral part of our office operation. (participant 11, line 1635)

In particular with Twitter, they might see something that they hadn't thought of before. It's like, "Oh, that person commented on this." or even better, "What is that person talking about? What do I need to know about it?" So it really is a way of getting a quick bit of information that either switches on a light bulb or triggers a question in the user - things that I wouldn't have thought of-you know, it's like, “Oh, you're right. (participant 21, line 5806)

In this category, practitioners' ethical reflections and concerns shifted from privacy and confidentially to issues of professional proficiency in social networking. Practitioners highlight the importance of ensuring that work-related activities in open social media settings are seen as professional, and they adopt an open social networking strategy, with a view to expanding their network in an open manner.

I'm happy to share my contacts. And so, you know, on LinkedIn I have it so that people can see my contacts, my connections. (participant 12, line 1750)

I've had people request to connect with me who I have no idea who they are. I probably never have talked to them but they have some sort of recruiting position in a firm that recruits in our school and I don't want to say no [...] I don't want to be sending a message that we're not interested in connecting. (participant 7 , line 699)

\section{Relationship between the categories}

The categories of description were delimited from each other and organised hierarchically through dimensions of variation that emerged from the data. Because of the hierarchical nature of categories, some conceptions can be characterised as wider than others (Åkerlind, 2005a). 
Career practitioners' approach to social networking changed across the categories of description. In Category 1, where ethical practice in social networking was informed by information orientation, the career practitioner's focus was on a particular technology tool and on what that tool could do. In Category 2, the focus shifted from the functionality of the technology to the content of networking connections. A key turning point then occurred in Category 3, where the emphasis shifted from a mainly procedurally focused (on technology and content) to a pedagogically focus on educational potential. In Category 4, the approach shifted again to a focus on strategic and systematic use for greatest impact.

Shifts in social networking activities appeared to transition from accessing and disseminating information to collaboration with and among community members. What separated Category 1 from the other categories was that social networking activities confined to accessing and disseminating information while the other categories focused on connecting and on building connections. In those latter categories, social networking activities extended to communication (Category 3 ) and collaborative career exploration (Category 4) with and among community members.

Level of usage was also differently characterised in each category. In the earlier categories, use of social networking was experimental (Category 1) or occasional (Category 2). Category 3 marked a change from non-regular to regular, daily use of social networking. In Category 4, there was a significant shift, as social networking became an integral part of career services and ethical practice was informed by collaborative orientation.

Perceptions of the use of social networking also varied across the categories. In Category 1, where ethical practice in social networking was informed by an information orientation, social networking technologies for professional purposes were perceived as challenging. In contrast, Category 2 embodied a more open stance, in which social networking was perceived as having potential. In the later categories, social networking was perceived as useful (Category 3) or influential (Category 4).

Ethical principles regarding the use of social networking varied across these categories. In Category 1 (information), ethical concerns related to accuracy and validity in obtaining and sharing information online. In Category 2 (networking) and Category 3 (educational), the ethical concerns shifted to professional boundaries and issues of privacy and confidentiality, respectively. In Category 4 (collaborative), the main ethical concerns related to professional proficiency in open social networking settings.

In terms of social networking strategy, there was transition across the categories from private to open social networking. Category 1 was distinct from other categories in its emphasis on private social networking strategy with profile restrictions. Category 2 was marked by a change from private to a semi-open, and selective social networking strategy, in which ethical practice was informed by networking orientation. Category 3 emphasised a targeted strategy, in which ethical practice was informed by an educational orientation. Finally, Category 4, where ethical practice was informed by a collaborative orientation, entailed an open social networking strategy. 


\section{Discussion}

In exploring career practitioners' conceptions of ethical practice in social networking, this study identified four distinct categories of description involving six dimensions of variation: approach to social networking, social networking activities, level of usage, perception, social networking strategy and ethical principles. While aligning with earlier studies, the findings also provide new insights into career practitioners' perceptions of ethical practice in social networking. The similarities with earlier studies (e.g., NACE, 2013; Osborn \& Lo-Frisco, 2012) relate mainly to the first three categories, where ethical practice in social networking was informed by information, networking and educational orientations. The present study echoes Sampson and Makela's (2014) observations on ethical issues in social networking, including accuracy and validity of resources, professional boundaries and issues of confidentiality and privacy. The findings also resonate with Kettunen's (2017) account of the requisite competencies for successful use of social media in career services, including information delivery, one-to-one communication, collaborative career exploration and co-careering.

In Category 4, there is a discernible shift towards a more open professional model (Watts, 2002) and towards more collective engagement (e.g., Kettunen et al., 2015a). This category articulated a system-focused approach to social networking. Here, social media becomes an integral part of career services, with an emphasis on methods and strategies for ensuring that work-related activities in open social media settings are seen as professional. The findings support Bratt's (2010) notion that while the practitioners can readily identify ethical issues in relation to social networking, they are not always sure how to deal with them.

This study provides an insight into practitioners' varying understandings of the ethical use of social networking in career services by exploring the logical relationships between qualitatively different conceptions. The matrix developed here serves as a catalyst for discussion of the perceived benefits and challenges described in the existing literature (e.g., Hooley et al., 2010; Kettunen et al., 2015a, 2015b; Makela, 2015). It also helps us to understand the different perspectives informing the reasoning of career professionals when they express ethical concerns or discuss potential strategies in relation to the use of social networking. By making career practitioners aware of these qualitatively different conceptions of ethical practice, the present findings can promote engagement in reflection on their own practice, highlighting issues they may previously have avoided or failed to notice. By acknowledging the differences between the categories and dimensions of variation, we can stimulate understanding and dialogue to facilitate learning.

The hierarchical structure of these findings can help career practitioners and trainers to deepen their ways of experiencing and understanding the ethical use of social media in career services. This is crucial if career practitioners are to adjust successfully to the paradigm shift, from delivering career services to co-careering, in that is emerging along with the social media (e.g., Kettunen, 2017). We would argue that it is important to develop training and support for the expansion 
of career practitioners' understanding of ethical use of social networking using the critical aspects that were identified in this study. Through training, career practitioners can become aware of their current ways of experiencing ethical practice in social networking and can envision ways of moving toward.

This study had some limitations. Participation in the study was voluntary, and data collected at a single point in time may not capture all the critical aspects or issues of relevance across the career service sector as a whole. For that reason, further studies are recommended, including pedagogical application of these results. To that end, future research should include the further development of pre-service and in-service training for career practitioners, based on the critical aspect identified here with follow-up investigation to clarify the applicability of the present findings. Further investigation of extended professional practice involving social networking is also strongly recommended.

Acknowledgements Open access funding provided by University of Jyväskylä (JYU).

Open Access This article is distributed under the terms of the Creative Commons Attribution 4.0 International License (http://creativecommons.org/licenses/by/4.0/), which permits unrestricted use, distribution, and reproduction in any medium, provided you give appropriate credit to the original author(s) and the source, provide a link to the Creative Commons license, and indicate if changes were made.

\section{References}

Ahlqvist, T., Bäck, A., Heinonen, S., \& Halonen, M. (2010). Road-mapping the societal transformation potential of social media. Foresight, 12(5), 3-26. https://doi.org/10.1108/14636681011075687.

Åkerlind, G. (2005a). Learning about phenomenography: Interviewing, data analysis and qualitative research paradigm. In J. A. Bowden \& P. Green (Eds.), Doing developmental phenomenography (pp. 63-73). Melbourne, Australia: RMIT University Press.

Åkerlind, G. S. (2005b). Variation and commonality in phenomenographic research methods. Higher Education Research \& Development, 24, 321-334. https://doi.org/10.1080/07294360500284672.

Åkerlind, G. S. (2008). A phenomenographic approach to developing academics> understanding of the nature of teaching and learning. Teaching in Higher Education, 13, 633-644. https://doi. org/10.1080/13562510802452350.

Åkerlind, G., Bowden, J. A., \& Green, P. (2005). Learning to do phenomenography: A reflective discussion. In J. A. Bowden \& P. Green (Eds.), Doing developmental phenomenography (pp. 74-100). Melbourne, Australia: RMIT University Press.

Barak, A. (2003). Ethical and professional issues in career assessment on the Internet. Journal of Career Assessment, 11, 3-21. https://doi.org/10.1177/106907202237457.

Barnes, A., La Gro, N., \& Watts, A. G. (2010). Developing e-guidance competencies: The outcomes of a two-year European project to transform the professional development of career guidance practitioners. Career Research and Development: The NICEC Journal, 25, 26-32.

Barnes, A., \& Watts, A. G. (2009). The conceptual framework-New map and new tools. In M. Silverii \& B. Busi (Eds.), ICT skills 2: ICT tools and training for e-guidance practitioners (pp. 17-21). Bologna, Italy: ASTER Scienza Tecnologia Impresa S. Cons p.a.

Bateman, P. J., Pike, J., \& Butler, B. S. (2010). To disclose or not: Publicness in social networking sites. Information Technology and People, 24, 78-100. https://doi.org/10.1108/09593841111109431.

Bimrose, J., Barnes, S.-A., \& Atwell, G. (2010). An investigation into the skills needed by connexions personal advisers to develop internet-based guidance. Reading: CfBT Education Trust.

Bimrose, J., Hughes, D., \& Barnes, S.-A. (2011). Integrating new technologies into careers practice: Extending the knowledge base. London, UK: UK Commission for Employment and Skills. 
Bogdan, R. C., \& Biklen, S. K. (2006). Qualitative research for education: An introduction to theories and methods (5th ed.). Boston, MA: Allyn \& Bacon.

Bonderup Dohn, N. (2009). Web 2.0: Inherent tensions and evident challenges for educationInternational. Journal of Computer Supported Collaborative Learning, 4, 343-363. https://doi.org/10.1007/s1141 2-009-9066-8.

Bowden, J. (2000a). Experience of phenomenographic research: A personal account. In J. Bowden \& E. Walsh (Eds.), Phenomenography (pp. 47-61). Melbourne, Australia: Royal Melbourne Institute of Technology.

Bowden, J. (2000b). The nature of phenomenographic research. In J. Bowden \& E. Walsh (Eds.), Phenomenography (pp. 1-18). Melbourne, Australia: Royal Melbourne Institute of Technology.

Bowden, J., \& Green, P. (Eds.). (2005). Doing developmental phenomenography. Melbourne, Australia: RMIT University Press.

Bowden, J. A., \& Green, P. J. (2010). Relationality and the myth of objectivity in research involving human participants. In J. Higgs, N. Cherry, R. Macklin, \& R. Ajjawi (Eds.), Researching practiceA discourse on qualitative methodologies (pp. 105-121). Rotterdam, The Netherlands: Sense.

Boyd, D. M., \& Ellison, N. B. (2007). Social network sites: Definition, history, and scholarship. Journal of Computer-Mediated Communication, 13, 210-230. https://doi.org/10.1111/j.1083-6101.2007.00393

Bratt, W. (2010). Ethical considerations of social networking for counsellors. Canadian Journal of Counselling and Psychotherapy, 44, 334-345.

Caers, R., \& Castelyns, V. (2010). LinkedIn and Facebook in Belgium: The influences and biases of social network sites in recruitment and selection procedures. Social Science Computer Review, 29, 437-448.

Carrillat, F. A., D’Astous, A., \& Morissette Grégoire, E. (2014). Leveraging social media to enhance recruitment effectiveness: A Facebook experiment. Internet Research, 24, 474-495.

Cedefop. (2009). Professionalising career guidance: Practitioner competences and qualification routes in Europe. Cedefop panorama series 164. Luxembourg: Office of the European Union.

Cogoi, C. (Ed.). (2005). Using ICT in guidance: Practitioner competences and training. Report of an EC Leonardo project on ICT skills for guidance counselors. Bologna, Italy: Outline Edizione.

DiLillo, D., \& Gale, E. B. (2011). To Google or not to Google: Graduate students' use of the Internet to access personal information about clients. Training and Education in Professional Psychology, 5, 160-166. https://doi.org/10.1037/a0024441.

Dyson, E. (2012). Face-to-Facebook: A blended approach to careers work. Journal of the National Institute for Career Education and Counselling, 29, 27-32.

Hooley, T., Hutchinson, J., \& Watts, A. G. (2010). Careering through the web. The potential of web 2.0 and 3.0 technologies for career development and career support services. London, UK: UK Commission for Employment and Skills.

IAEVG [International Association for Educational and Vocational Guidance]. (2017). IAEVG Ethical Guidelines. Retrieved from http://iaevg.net/wp-content/uploads/IAEVG-EthicsNAFeb2018Final .pdf.

Jobvite. (2013). Jobvite Survey: Social Recruiting Survey 2013.

Jobvite. (2014). 2014 Jobvite Job Seeker Nation Study.

Kettunen, J. (2017). Career practitioners' conceptions of social media and competency for social media in career services. Jyväskylä, Finland: University of Jyväskylä, Finnish Institute for Educational Research. Studies, 32. Dissertation.

Kettunen, J., \& Sampson, J. P., Jr. (2018). Challenges in implementing ICT in career services: Perspectives from career development experts. International Journal for Educational and Vocational Guidance. https://doi.org/10.1007/s10775-018-9365-6.

Kettunen, J., Sampson, J. P., \& Vuorinen, R. (2015a). Career practitioners' conceptions of competency for social media in career services. British Journal of Guidance and Counselling, 43, 43-56. https:// doi.org/10.1080/03069885.2014.939945.

Kettunen, J., \& Tynjälä, P. (2017). Applying phenomenography in guidance and counseling research. British Journal of Guidance and Counselling. https://doi.org/10.1080/03069885.2017.1285006.

Kettunen, J., Vuorinen, R., \& Ruusuvirta, O. (2016). European Lifelong Guidance Policy Network representatives' conceptions of the role of information and communication technologies related to national guidance policies. International Journal for Educational and Vocational Guidance, 16, $327-342$. 
Kettunen, J., Vuorinen, R., \& Sampson, J. P., Jr. (2013). Career practitioners' conceptions of social media in career services. British Journal of Guidance \& Counselling, 41, 302-317. https://doi. org/10.1080/03069885.2014.781572.

Kettunen, J., Vuorinen, R., \& Sampson, J. P. (2015b). Practitioners' experiences of social media in career services. The Career Development Quarterly, 63, 268-282. https://doi.org/10.1002/cdq.12018.

Kitzinger, J., \& Barbour, R. S. (1999). Introduction: The challenges and promise of focus groups. In R. S. Barbour \& J. Kitzinger (Eds.), Developing focus group research (pp. 1-20). London, UK: Sage.

Kolbitsch, J., \& Maurer, H. (2006). The transformation of the web: How emerging communities shape the information we consume. Journal of Universal Computer Science, 12, 187-213.

Krueger, R. A. (1997a). Developing questions for focus groups: Focus group kit 3. Thousand Oaks, CA: Sage.

Krueger, R. A. (1997b). Moderating focus groups: Focus group kit 4. Thousand Oaks, CA: Sage.

Krueger, R. A. (1998). Analyzing \& reporting focus group results: Focus group kit 6 . Thousand Oaks, CA: Sage.

Makela, J. P. (2015). Ethical use of social networking technologies in career services. Broken Arrow, OK: National Career Development Association.

Malone, J. F. (2007). Ethical guidelines, legal and regulatory issues in distance counseling. In J. F. Malone, R. M. Miller, \& G. R. Walz (Eds.), Distance counseling: Expanding the counselor's reach and impact (pp. 133-148). Ann Arbor, MI: Counseling Outfitters.

Marton, F. (1986). Phenomenography-A research approach investigating different understandings of reality. Journal of Thought, 21, 28-49.

Marton, F., \& Booth, S. (1997). Learning and awareness. Mahwah, NJ: Lawrence Erlbaum Associates.

Marton, F., \& Pong, Y. W. (2005). On the unit of description in phenomenography. Higher Education Research \& Development, 24, 335-348. https://doi.org/10.1080/07294360500284706.

Melanthiou, Y., Pavlou, F., \& Constantinou, E. (2015). The use of social network sites as an E-recruitment tool. Journal of Transnational Management, 20, 31-49.

NACE [National Association of Colleges and Employers]. (2013). Career services use of social media technologies. Retrieved from: http://www.careeradvisoryboard.org/research/career-services-use-ofsocial-media-technologies-may-2013.html.

NCDA [National Career Development Association]. (2015). 2015 National Career Development Association Code of Ethics. Broken Arrow, OK. Retrieved from http://www.ncda.org/aws/NCDA/asset _manager/get_file/3395.

Niles, S. G., \& Harris-Bowlsbey, J. (2013). Career development interventions in the 21st century (4th ed.). Boston, MA: Pearson.

Nykänen, S. (2011). Towards leadership and management in guidance and counselling networks in Finland. Jyväskylä, Finland: University of Jyväskylä.

Osborn, D. S., Dikel, M. R., \& Sampson, J. P. (2011). The internet: A tool for career planning (3rd ed.). Broken Arrow, OK: National Career Development Association.

Osborn, D. S., \& LoFrisco, B. M. (2012). How do career centers use social network- ing sites? The Career Development Quarterly, 60, 263-272. https://doi.org/10.1002/j.2161-0045.2012.00022.x.

Patton, M. Q. (2002). Qualitative research \& evaluation methods (3rd ed.). Thousand Oaks, CA: Sage.

Pyle, K. R. (2000). Career counseling in an information age: The promise of "high touch" in a "high tech" age. Career Planning and Adult Development Journal, 16(3), 7-29.

Sampson, J. P., Jr. (2002). Quality and ethics in internet-based guidance. International Journal for Educational and Vocational Guidance, 2, 157-171. https://doi.org/10.1023/a:1020665316813.

Sampson, J. P., Jr., \& Makela, J. P. (2014). Ethical issues associated with information and communication technology in guidance. International Journal for Educational and Vocational Guidance, 1, 135-148. https://doi.org/10.1007/s10775-013-9258-7.

Trigwell, K. (2000). A phenomenographic interview on phenomenography. In J. A. Bowden \& E. Walsh (Eds.), Phenomenography (pp. 62-82). Melbourne, Australia: RMIT University Press.

Van Allen, J., \& Roberts, M. C. (2011). Critical incidents in the marriage of psychology and technology: A discussion of potential ethical issues in practice, education, and policy. Professional Psychology: Research and Practice, 42, 433-439. https://doi.org/10.1037/a0025278.

Watts, A. G. (2002). The role of information and communication technologies in integrated career information and guidance systems: A policy perspective. International Journal for Educational and Vocational Guidance, 2, 139-155. https://doi.org/10.1023/a:1020669832743. 


\section{Affiliations}

\section{Jaana Kettunen $^{1}$ (1) Julia Panke Makela ${ }^{2}$}

$\triangle$ Jaana Kettunen

jaana.h.kettunen@jyu.fi

1 Finnish Institute for Educational Research, University of Jyväskylä, P.O. Box 35, 40014 Jyväskylä, Finland

2 Career Center, University of Illinois at Urbana-Champaign, Champaign, USA 